\title{
Short commentary on marine productivity at Arctic shelf breaks: upwelling, advection and vertical mixing
}

\author{
Achim Randelhoff ${ }^{1, a}$ and Arild Sundfjord ${ }^{1}$ \\ ${ }^{1}$ Norwegian Polar Institute, Fram Centre, 9296 Troms $\emptyset$, Norway \\ anow at: Québec-Océan and Takuvik, Département de biologie, Université Laval, Québec, Canada
}

Correspondence: Achim Randelhoff (achim.randelhoff@takuvik.ulaval.ca)

Received: 10 August 2017 - Discussion started: 30 August 2017

Revised: 23 March 2018 - Accepted: 27 March 2018 - Published: 18 April 2018

\begin{abstract}
The future of Arctic marine ecosystems has received increasing attention in recent years as the extent of the sea ice cover is dwindling. Although the Pacific and Atlantic inflows both import huge quantities of nutrients and plankton, they feed into the Arctic Ocean in quite diverse regions. The strongly stratified Pacific sector has a historically heavy ice cover, a shallow shelf and dominant upwelling-favourable winds, while the Atlantic sector is weakly stratified, with a dynamic ice edge and a complex bathymetry. We argue that shelf break upwelling is likely not a universal but rather a regional, albeit recurring, feature of "the new Arctic". It is the regional oceanography that decides its importance through a range of diverse factors such as stratification, bathymetry and wind forcing. Teasing apart their individual contributions in different regions can only be achieved by spatially resolved time series and dedicated modelling efforts. The Northern Barents Sea shelf is an example of a region where shelf break upwelling likely does not play a dominant role, in contrast to the shallower shelves north of Alaska where ample evidence for its importance has already accumulated. Still, other factors can contribute to marked future increases in biological productivity along the Arctic shelf break. A warming inflow of nutrient-rich Atlantic Water feeds plankton at the same time as it melts the sea ice, permitting increased photosynthesis. Concurrent changes in sea ice cover and zooplankton communities advected with the boundary currents make for a complex mosaic of regulating factors that do not allow for Arctic-wide generalizations.
\end{abstract}

\section{Introduction}

Surface waters throughout most of the world ocean are generally low in nutrients. In order to sustain primary production, new nutrients are required. These can come by means of mineral-rich rivers draining into coastal areas, turbulent small-scale mixing where underlying waters are rich in nutrients, upwelling of deeper nutrient-rich waters or even nitrogen fixation by some bacteria. In fact, upwelling in certain coastal areas and at shelf breaks in many regions of the world ocean supports intense marine production and can sustain rich regional fisheries (see e.g. Kämpf and Chapman, 2016). Where upwelling occurs, it is often intimately linked to specific weather and climate patterns, such as storms (cyclones), or wind blowing from a preferential direction. The basic concept is that the winds set up spatially varying surface transport or force surface water away from the coast, creating a divergence that draws up deeper waters which would otherwise be too heavy to be brought up by vertical mixing alone (Kämpf and Chapman, 2016).

Shelf break upwelling has recently received increasing attention also in the Arctic Ocean (Carmack and Chapman, 2003; Arrigo and van Dijken, 2015; Williams and Carmack, 2015, and more references below; for an overview of the geography, see Fig. 1). As the ice edge recedes from the shelves into the basin further and further each year (e.g. Stroeve et al., 2012), net primary production has been observed to have increased Arctic-wide (Arrigo and van Dijken, 2011; Bélanger et al., 2013; Arrigo and van Dijken, 2015). Not only would less ice allow more solar radiation into the ocean, providing more of a scarce requirement for photosynthesis, but it is also assumed that winds can move the surface waters more effectively and lead to more pronounced shelf break upwelling 
(Carmack and Chapman, 2003). This is another aspect of the Arctic as the region of the world where the impacts of climate change are most pronounced.

\section{Upwelling in the Arctic}

In their seminal 2003 paper mentioned above, Carmack and Chapman applied a numerical model to study shelf-basin exchange on the Beaufort Sea shelf and argued that decreased ice concentrations will enhance upwelling in the area. The argument goes like this: when a thick ice cover lies like a lid on the ocean, it absorbs most of the wind stress instead of transferring it to the underlying ocean. When the ice edge recedes far enough north that the shelf break is exposed, however, the winds can move around the surface waters more easily. Sustained easterlies, for example, will lead to a northward Ekman transport, and where the shelf is shallow enough that it affects surface currents (see Figs. 2 and 3), deeper waters are drawn up to balance the off-shelf transport.

This argument was reinforced by a number of studies conducted in the Pacific Arctic (Williams et al., 2006; Schulze and Pickart, 2012; Spall et al., 2014; Arrigo et al., 2014; Lin et al., 2016), which directly extended earlier direct observations of shelf break upwelling dating back to at least the 1980s (e.g. Aagaard et al., 1981). A detailed study (Spall et al., 2014) on the dynamic response during one particularly impressive example of shelf break upwelling in the Chukchi Sea (Arrigo et al., 2014) demonstrated potentially large contributions to primary productivity in that area.

The idea has since caught on to explain or project marine productivity also in other regions of the Arctic Ocean, for example at the Barents Sea shelf break. There it has appeared both in numerous personal communications among the community working with the physical and ecological environment of the Barents Sea and a number of published articles (see e.g. Falk-Petersen et al., 2014; Tetzlaff et al., 2014; Wassmann et al., 2015; Hunt et al., 2016; Våge et al., 2016; Haug et al., 2017). Thus it might appear as if shelf break upwelling is currently being cemented as a universal paradigm to conceptualize the "new" Arctic Ocean where global climate change is taking us. We will argue that some of the regional differences cannot be ignored when discussing what governs productivity in the various shelf regions.

\section{Many interconnected phenomena}

Upwelling comes in many different forms: the well-known upwelling that feeds so many productive coastal areas of the world is created by winds blowing along-shore, driving an offshore surface current that "pulls up" nutrient rich waters. (This will in practice most often be the Ekman transport; however, shelf break upwelling would function in much the same way at the Equator where there is no Coriolis force, even though upwelling-favourable winds would then blow directly off-shelf instead of along-shelf.) The divergence sets up a horizontal gradient in sea surface height that balances the Coriolis force, meaning that deeper waters are drawn towards the surface and/or onto the shelf (again, see e.g. Kämpf and Chapman, 2016).

Alternatively, storms can lift deeper waters up to the shelf break, making them spill over and mix with shelf waters. Canyons and troughs that cut into a continental shelf may aid by steering the flow there through its topography. All of these phenomena can act together to bring new nutrients into shelf waters.

But besides upwelling, other factors are at play. Two important ones are vertical mixing and advection with largescale ocean currents, and both of them can become entangled with upwelling in that they can lead to similar effects in the regional oceanography and be hard to tell apart by the most basic means of hydrography, which are vertical profiles of temperature and salinity. Because different areas within the Arctic Ocean are subject to very different forcing, large gradients in physical properties exist between e.g. the Bering Strait, Fram Strait and the Siberian Shelf. Naturally, this means that the drivers of marine productivity will also vary strongly between these areas.

\section{Drivers of marine productivity vary across the Arctic Ocean}

There is an ample storage of fresh water in the Arctic Ocean because of the large rivers draining Siberia and North America, but also because the inflow of Pacific Water through the Bering Strait is much fresher than its Atlantic counterpart (Aagaard and Carmack, 1989). But the fresh water is not evenly distributed: most of it is found in the Beaufort Gyre located around the Canadian Basin (e.g. Morison et al., 2012; Proshutinsky et al., 2015). When light water (at low temperatures, this means fresher) sits on top of heavy water, mixing will not be as efficient (e.g. Osborn, 1980), which means that the most important factor for vertical mixing is vertical stability (since overall, there is a given amount of energy available to stir the ocean, e.g. from tides, wind and so on.) In the Beaufort Gyre, all the fresh water and the resulting strong stratification severely restrict the upward supply of fresh nutrients, making it one of the most nutrient-depleted regions of the world ocean (Gruber and Sarmiento, 1997; Codispoti et al., 2013; Tremblay et al., 2015).

In contrast, the Atlantic inflow along the shelf break north of Svalbard is much denser than the surface waters of the central Arctic Ocean, but nevertheless extends up to the surface (see e.g. Rudels, 2016, an illustration is also given in Fig. 4). Seeing this situation in the contour plot of a hydrographic transect (see Fig. 4b) may at first look like a classical upwelling scenario: surely there must have been upwelling to get the heavy waters up there in the first place? The answer is not necessarily - what we are seeing is Arctic and Atlantic 

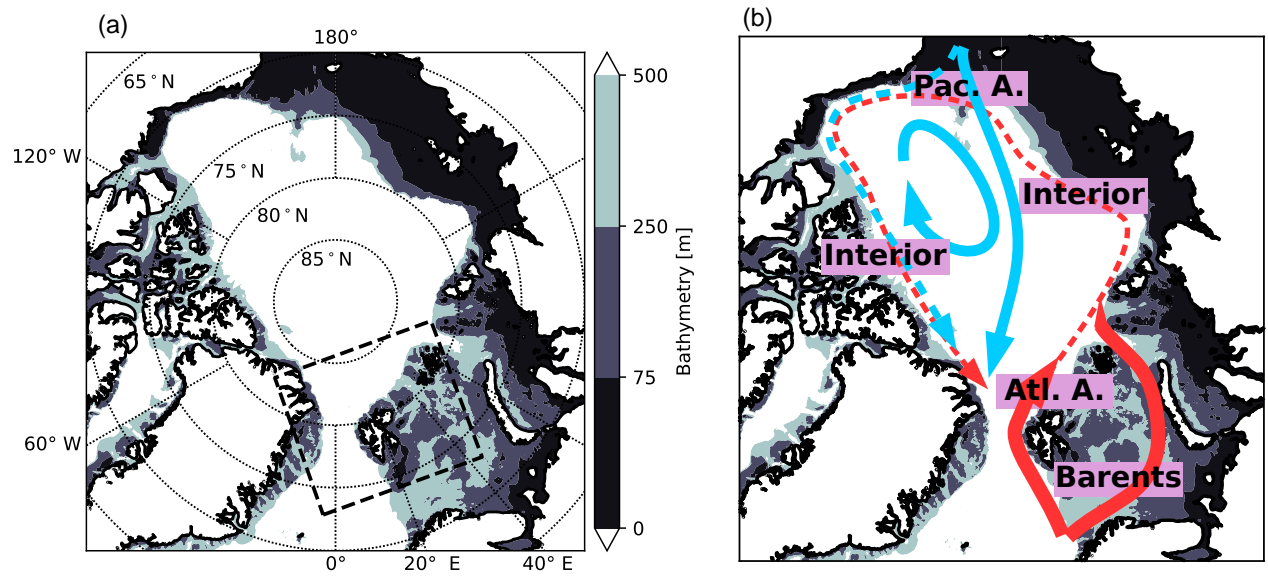

Figure 1. Map of the Arctic Ocean (based on Jakobsson et al., 2012) indicating the general geographic regimes. (a) Bathymetry of the shelf and shelf break area. The box in dashed lines shows the area in Fig. 4a. (b) The Pacific Arctic, Atlantic Arctic, interior shelves (following Williams and Carmack, 2015) and the Barents Sea. Arrows show selected patterns of the general circulation (after Polyakov et al., 2012). Blue arrows: Pacific-derived and other fresh water flowing along the shelf break through the Transpolar Drift and in the Beaufort Gyre. Red arrows: Atlantic-derived water entering the Arctic Ocean through the Fram Strait and the Barents Sea, submerging north of the Barents Sea and recirculating along the shelf break through the Arctic Ocean. Other major currents are not indicated here as they are of minor importance to this paper.

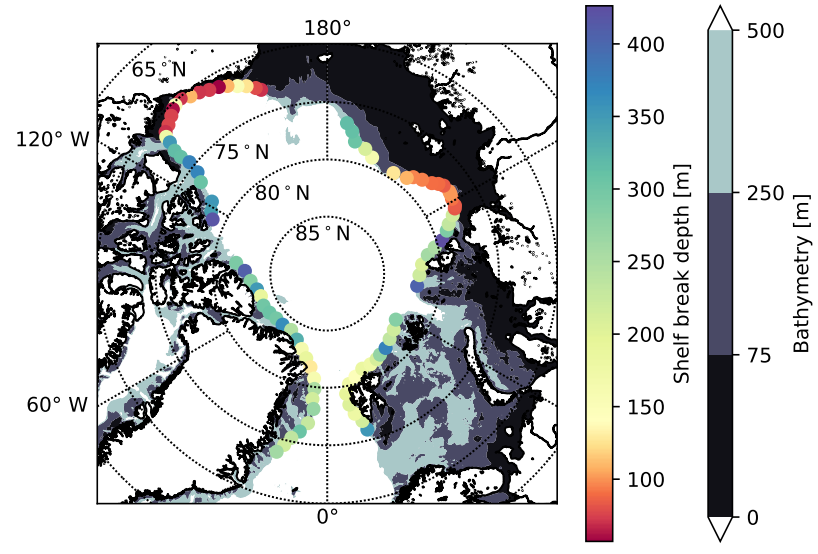

Figure 2. Depth of the Arctic shelf break extracted from the IBCAO V3 bathymetry of the Arctic Ocean (Jakobsson et al., 2012), excluding only the Saint Anna Trough and the Chukchi Borderland. Most visible are the continental shelf off Alaska and the westernmost part of the Canadian shelf, where Carmack and Chapman (2003) conducted their study and upwelling has been frequently documented, and north of the Laptev Sea. In most other areas of the Arctic Ocean, the shelf break is several hundred metres deep and therefore out of reach to interact significantly with Ekman-driven surface ocean dynamics. For a detailed explanation of the algorithm and the computer code used to extract shelf break depths, see the Supplement.

water masses meeting, and the narrow but strong gradient is maintained by a continuous inflow of more Atlantic Water. In the absence of detailed (hydrographic) time series, it is impossible to say anything conclusive about the state of upwelling from Fig. $4 \mathrm{~b}$ alone.

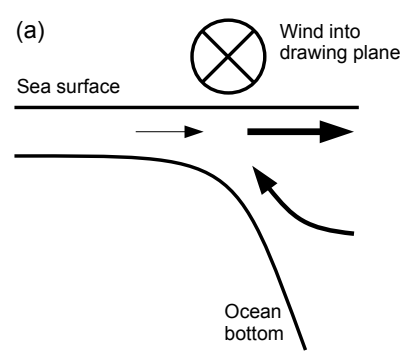

(b)

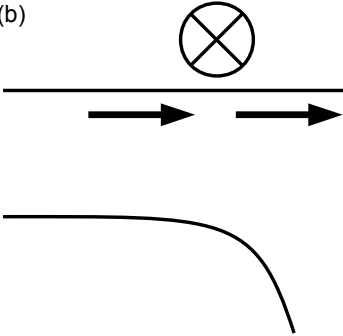

Figure 3. Schematic of the mechanism behind wind-driven shelf break upwelling. When wind blows along the shelf break, it generates an Ekman current (horizontal arrows) off-shelf. (a) When the shelf is shallow enough, the current over the shelf is slowed down, leading to a horizontal divergence and thus pressure gradient that is filled by drawing up deeper waters. (b) When the shelf is deeper, there is no horizontal divergence. Other mechanisms, such as dynamic uplift, are independent from wind and not discussed here, but see e.g. the book by Kämpf and Chapman (2016).

We thus need to distinguish between basin-scale and regional hydrography; that is, between strong haline stratification in the Arctic Ocean in general and weak thermal stratification in the Atlantic inflow (see the distinction between "alpha" and "beta" oceans as in Carmack, 2007). The salient point is this: as the Atlantic Water is cooled on its way north, it loses stability, potentially leading to wintertime convection (Ivanov et al., 2016) and efficient vertical mixing. The result is that the surface layer nutrient reservoirs are replenished long before the end of winter (Randelhoff et al., 2015); increased wintertime upwelling will not bring more nutrients 

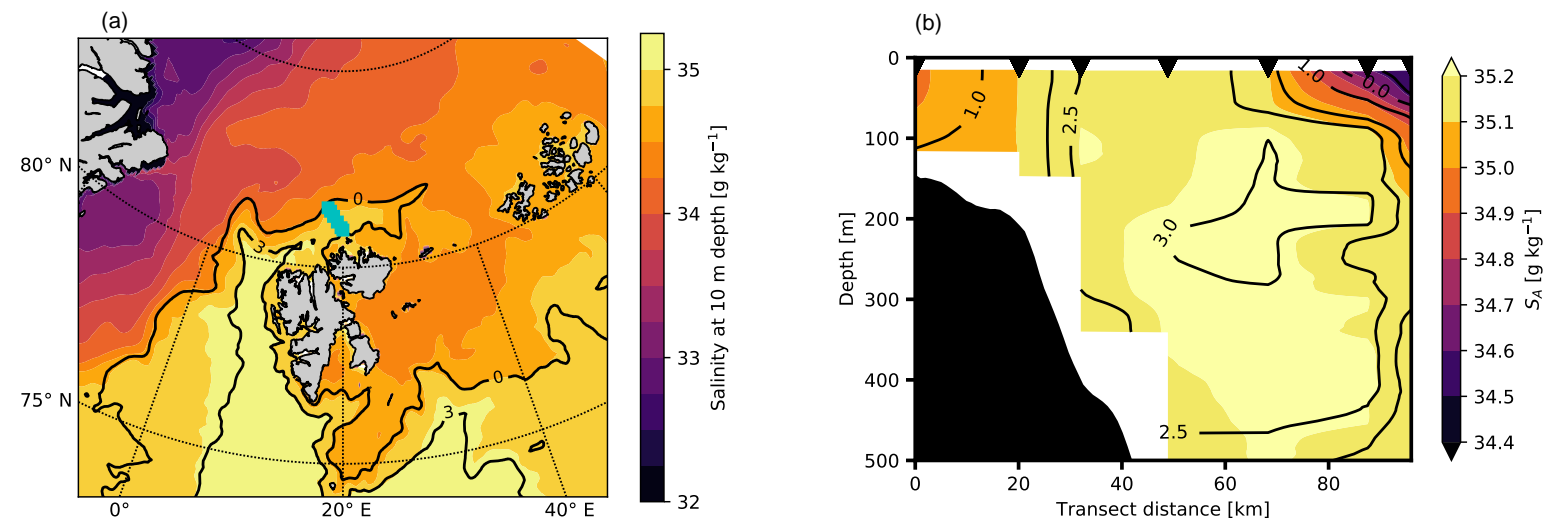

Figure 4. Representative illustration of the hydrographic regime in the Atlantic inflow area along the northern Barents Sea shelf break. (a) Inflowing warm and salty Atlantic Water maintains high surface salinity on and around the shelf, enabling convection when the surface waters are cooled in winter. The colour scale shows salinity, and the black contour lines show the 0 and $3^{\circ} \mathrm{C}$ isotherms (average of $2015-2018$ monthly January mean at $10 \mathrm{~m}$ of depth from the operational ocean reanalysis Mercator, downloaded from http://marine.copernicus.eu (last access: 7 March 2018); the version of Mercator used for this plot is a global ocean forecasting model on a $1 / 12^{\circ} \times 1 / 12^{\circ}$ grid and showed good agreement with winter data for this area in a study by Koenig et al., 2017). The cyan line indicates the location of the transect displayed in panel (b). (b) Seawater absolute salinity $S_{\mathrm{A}}$ and conservative temperature in a typical wintertime transect across the shelf slope north of Svalbard; sampled in January 2014. Data from approximately $81.5^{\circ} \mathrm{N}, 17.5^{\circ} \mathrm{E}$; RV Helmer Hanssen, Carbon Bridge project (Randelhoff and Sundfjord, 2017, published dataset; see also Randelhoff et al. 2018); see panel (b) for location. Salinity is plotted on the colour scale, and temperature is marked (in ${ }^{\circ} \mathrm{C}$ ) on the black isolines inside the plot. The surface water is markedly heavier above the upper shelf slope than over the deep basin. Black triangles mark hydrographic stations. The black patch marks the along-transect bathymetry extracted from the IBCAO V3 bathymetry (Jakobsson et al., 2012). During the sampling of this transect, winds were moderate southerlies to south-south-easterlies, so mean Ekman transport in the surface was mainly directed along-shelf to the east.

to the surface. Essentially, the upwelling water mass would have the same salinity and nutrient characteristics as the one that is already present in the surface; upwelling does not add nutrients when there is no vertical gradient in nutrient concentrations. In contrast, the Beaufort Sea is strongly stratified throughout the year; if winter upwelling is to increase there because of reduced sea ice, this can be an important factor contributing to the pre-bloom nutrient pool.

In contrast to storms, which can lift deeper waters independently from any sort of topographic constraint (i.e. Ekman pumping), coastal and shelf break upwelling driven by specific wind directions need the presence of a coastline or a sufficiently shallow shelf. This is because they require a horizontal divergence in the off-shelf transport of surface waters. This divergence can only be potent enough when the shelf itself is shallow enough to actually constrict the surface flow over the shelf (Fig. 3). Whereas large swaths of the continental shelves of the Arctic Ocean are very shallow (in parts less than $50 \mathrm{~m}$ ), the Northern Barents Sea shelf break is relatively deep at around 150-250 m (see Fig. 2). Because surface and bottom boundary layers will not overlap in this case (common values for Ekman layer depth in the literature are only a few tens of metres; see Price and Sundermeyer, 1999), shelf break upwelling as an effect of along-shore winds is presumably negligible. Also note that Ekman layer depth decreases with increasing latitude and decreasing wind strength (Wang and Huang, 2004) and that during the stratified summer pe- riod, the Ekman layer will at any rate be restricted to at most the surface mixed layer (see e.g. Price et al., 1987).

In general, the regions that (only based on the depth of the shelf break) stand out as most prone to wind-driven shelf break upwelling are the aforementioned continental shelves of Alaska, the westernmost part of northern Canada and possibly the Laptev Sea, although the shelf is rather wide here, potentially diminishing the effect of easterlies somewhat. In regions where the shelf is narrow, the presence of the coastline can aid in the upwelling of deeper waters. Seeing that the Chukchi and Siberian shelves are rather wide, potential upwelling will likely be relatively weak across large swaths of the Arctic shelf regions.

\section{Summertime upwelling north of Svalbard?}

We have seen how the pre-bloom surface nutrient inventory at the northern Barents Sea shelf break can be replenished just by the inflowing Atlantic Water, without recourse to wintertime upwelling. In summer, however, nutrients are depleted in surface waters such that even sporadic upwelling could inject nutrients that could be utilized immediately and funnelled into the food web (see e.g. Sect. 3.2 in Kämpf and Chapman, 2016). 


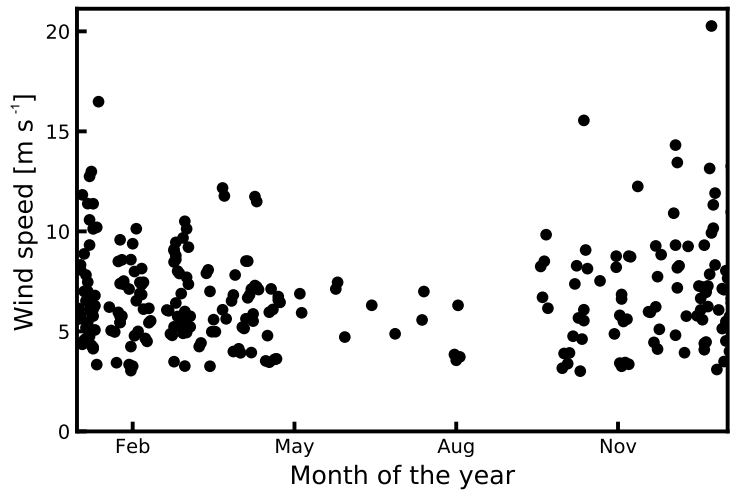

Figure 5. Days of "potentially upwelling-favourable" winds north of Svalbard 1987-2017, assuming that the local bathymetry facilitates such upwelling, based on ERA-Interim data (Dee et al., 2011) for the region $79-81^{\circ} \mathrm{N}, 5-30^{\circ} \mathrm{E}$. A daily wind speed was considered "potentially upwelling-favourable" if its (approximately easterly) along-shelf component exceeded $3 \mathrm{~m} \mathrm{~s}^{-1}$ for at least 3 consecutive days. $\left(3 \mathrm{~m} \mathrm{~s}^{-1}\right.$ is a rather low wind speed, well below the "optimal environmental window" of 5-6 $\mathrm{m} \mathrm{s}^{-1}$ for upwelling suggested by Cury and Roy (1989) and makes for a generous criterion in this regard. Likewise, Kämpf and Chapman (2016, Sect. 2.1) give a timescale of around 5 days from the onset until the complete development of coastal upwelling. Effectively, both criteria should err on the upwelling-favourable side.) From the beginning of May through August each year, $\sim 2 \%$ of all days were "potentially upwelling-favourable".

Here, another difference between the Atlantic and Pacific inflow areas comes into play, namely dominant wind patterns: the Beaufort Sea shelf is dominated by the Beaufort High-Aleutian Low system, meaning predominantly easterlies at the Canadian shelf break (e.g. Serreze and Barrett, 2011). The atmospheric circulation in the Atlantic sector is more dynamic in summer, with less of a preference for a specific upwelling-favourable wind direction (see e.g. Fig. 5). This comes on top of a general pattern in which wind speeds north of Svalbard are lower in summer than in winter. Fig. 5 illustrates how only roughly $2 \%$ of all summer days through the last 30 years can be considered upwellingfavourable using a very generous criterion for what constitutes "upwelling-favourable", and even this is assuming that the local topography would allow for this kind of upwelling. (Again, note the difference to the Beaufort shelf where winds are very upwelling-favourable also in June; see Lin et al., 2016.) There might still be storms that make deeper waters spill onto the shelf by Ekman pumping alone, but these also have a tendency to occur more frequently in the winter season (see also Lind and Ingvaldsen, 2012).

As has been shown above, wind statistics as well as general physical considerations and geographical features - the northern Barents Sea shelf being too deep for surface and bottom Ekman layers to overlap and produce shelf break upwelling - imply that upwelling should not be expected to feature very prominently on the Barents side of the Arctic. This is not to say that upwelling events cannot ever happen (and indeed, in a system as complex as the Earth, it would be surprising if it never happened), but no known physical mechanism would suggest a magnitude, frequency or importance similar to what has been found in the Pacific sector. To illustrate our point, we refer to recent analysis by A. Renner and collaborators. They have analysed the first year-long time series from a moored CTD array over the shelf slope north of the Barents Sea (A-TWAIN project at $30^{\circ} \mathrm{E}$ ). By applying methods that have successfully detected the frequent occurrence of upwelling over the Beaufort Sea slope (Lin et al., 2016), they could not identify signatures of upwelling in the density field in response to possibly favourable alongslope winds (Angelika H. H. Renner, personal communication, 2017, and Renner et al., 2018).

\section{Climate change and the future of Arctic marine productivity}

Shelf break upwelling is often thought of as becoming more prominent in the Arctic as the ice recedes poleward with ongoing climate change, exposing the shelf break more and more (see references given in the previous section "Upwelling in the Arctic"). But it should be kept in mind that the mere earlier presence of an ice cover would not have prohibited wind-driven upwelling (or Ekman pumping) and could even have enhanced it in some circumstances. For instance, Martin et al. (2014) showed how a loose ice cover (80-90\% ice concentration) can yield an optimum transfer of wind energy into the upper ocean when internal ice stresses are negligible because sea ice has a rougher surface than open water and can therefore be moved around more easily by the winds. This is consistent with the observation of Schulze and Pickart (2012) that the upwelling response at the Beaufort Sea shelf off Alaska was strongest when there was partial ice cover. Once again, there are differences between the historically thick, multi-year ice cover of the Pacific Arctic (Maslanik et al., 2007) and the more dynamic first- and second-year ice cover north of Svalbard (Renner et al., 2013). In the latter area, it is not a new feature that the ice cover is quite dynamic and rough, which possibly leads to an efficient transfer of wind energy as was demonstrated in the previously mentioned paper by Martin et al. (2014). It is therefore not a given that reduced ice cover north of Svalbard will automatically make surface currents more responsive than they were in the past, especially under the responsive summer pack ice when upwelling has the chance to substantially alter the marine ecosystem through sporadic nutrient input.

In fact, there are pathways entirely unrelated to upwelling through which climate change is probably impacting and enhancing marine productivity. Indeed, the regional loss of sea ice has been attributed to the inflow of warmer Atlantic Water (Onarheim et al., 2014). As the Atlantic Water travels further 
and further east along the shelf break before it is sufficiently cooled and its core is subsequently subducted under the Arctic water masses, it pushes back the ice edge and erodes stratification (Polyakov et al., 2017) - meaning it provides access to nutrients and light at the same time! This will enhance regionally averaged primary production by itself, without the need to invoke shelf break upwelling.

In addition to heat, salt and nutrients, the Atlantic (like the Pacific) water also carries large amounts of zooplankton. This makes the inflow areas perfect feeding grounds for larger fish and mammals, adding to local primary production. For instance, there is an excess of organic carbon production NW of Spitsbergen in May and June (Maria Vernet, personal communication, 2017), in agreement with modelling results (e.g. Wassmann et al., 2015). As sea ice recedes northward and eastward, it might extend this region of net heterotrophy (carbon consumption). However, results from a coupled ocean and ecosystem model indicate that by the end of the 21 st century, zooplankton advection along the shelf break will dwindle, and marine life in the area might rely much more on local production (Wassmann et al., 2015). Such processes would contrast a projected pan-Arctic strengthening of upper ocean stratification that might lead to a smaller plankton size spectrum, fuelling a food web that recycles more than providing food for higher trophic levels (e.g. Li et al., 2009, 2013).

\section{Summary and conclusions}

Detailed measurements and analyses with spatial and temporal resolution are necessary in order to detect upwelling in general; shelf break upwelling in the Arctic is no exception. In general, moored CTD arrays in conjunction with wind data are a solid foundation to detect upwelling in the field; hydrographic snapshots are rarely enough to establish its dynamics and drivers. The 2-D modelling approach of Spall et al. (2014) has proven particularly valuable for mapping upwelling-driven nutrient transport across the Beaufort Sea shelf break, and a similar model could yield essential insight in other areas of the Arctic Ocean as well. Furthermore, the role of "dynamic uplift" (Kämpf and Chapman, 2016, Sect. 2.1), through which e.g. eddy shedding of a boundary current can lead to changes in its position onto the shelf, for shelf-basin exchange is not yet well understood in this area.

More generally, it would appear that changes in crossshelf exchange are most important for the interior shelves (Williams and Carmack, 2015) where nutrients are rather scarce to begin with. There is a projection that continued warming will release organic nutrients bound in the permafrost landscapes of northern Siberia and Alaska and flush them out into the Arctic Ocean (Frey and McClelland, 2009). Beyond these, rivers do not carry significant amounts of nitrate, one of the scarcest and most important mineral nutrients in the Arctic Ocean. Profound changes in the on- shelf transport of nutrient-rich water from the Atlantic Water boundary current might thus have big impacts on integrated productivity. Changes in the position of the ice edge can also effect changing storm tracks and hence Ekman pumping. This too is a complex issue and there are no clear answers regarding its effect on nutrient transport onto the shelf.

Whatever the final result, Arctic marine life will find itself in a vastly different habitat within a tangible number of decades, showcasing the Arctic as a region where drastic changes are happening fast and, equally important, nonlinearly. This also means that even dynamically isolated phenomena have to be evaluated against their specific regional backgrounds.

Data availability. The data shown in Fig. $4 \mathrm{~b}$ are available at https:// doi.org/10.21334/npolar.2017.f40317d5 (2017; see the references). The algorithm used to generate Fig. 2 is published in detail in the Supplement.

Supplement. The supplement related to this article is available online at: https://doi.org/10.5194/os-14-293-2018-supplement.

Competing interests. The authors declare that they have no conflict of interest.

Acknowledgements. We thank Randi Ingvaldsen for very useful feedback and discussions on an earlier draft of the paper. Achim Randelhoff was funded by the project Carbon Bridge, a Polar Programme (project 226415) funded by the Norwegian Research Council.

Edited by: Mario Hoppema

Reviewed by: three anonymous referees

\section{References}

Aagaard, K. and Carmack, E. C.: The role of sea ice and other fresh water in the Arctic circulation, J. Geophys. Res.-Oceans, 94, 14485-14498, https://doi.org/10.1029/JC094iC10p14485, 1989.

Aagaard, K., Coachman, L., and Carmack, E.: On the halocline of the Arctic Ocean, Deep-Sea Res., 28, 529-545, 1981.

Arrigo, K.-R. and van Dijken, G.-L.: Secular trends in Arctic Ocean net primary production, J. Geohpys. Res., 116, C09011, https://doi.org/10.1029/2011jc007151, 2011.

Arrigo, K. R. and van Dijken, G. L.: Continued increases in Arctic Ocean primary production, Prog. Oceanogr., 136, 60-70, https://doi.org/10.1016/j.pocean.2015.05.002, Synthesis of Arctic Research (SOAR), 2015.

Arrigo, K. R., Perovich, D. K., Pickart, R. S., Brown, Z. W., van Dijken, G. L., Lowry, K. E., Mills, M. M., Palmer, M. A., Balch, W. M., Bates, N. R., Benitez-Nelson, C. R., Brownlee, E., Frey, K. E., Laney, S. R., Mathis, J., Mat- 
suoka, A., Mitchell, B. G., Moore, G., Reynolds, R. A., Sosik, H. M., and Swift, J. H.: Phytoplankton blooms beneath the sea ice in the Chukchi Sea, Deep-Sea Res. Pt. II, 105, 1-16, https://doi.org/10.1016/j.dsr2.2014.03.018, 2014.

Bélanger, S., Babin, M., and Tremblay, J.-É.: Increasing cloudiness in Arctic damps the increase in phytoplankton primary production due to sea ice receding, Biogeosciences, 10, 4087-4101, https://doi.org/10.5194/bg-10-4087-2013, 2013

Carmack, E. and Chapman, D. C.: Wind-driven shelf/basin exchange on an Arctic shelf: The joint roles of ice cover extent and shelf-break bathymetry, Geophys. Res. Lett., 30, 1778, https://doi.org/10.1029/2003g1017526, 2003.

Carmack, E. C.: The alpha/beta ocean distinction: A perspective on freshwater fluxes, convection, nutrients and productivity in high-latitude seas, Deep-Sea Res. Pt. II, 54, 2578-2598, https://doi.org/10.1016/j.dsr2.2007.08.018, 2007.

Codispoti, L., Kelly, V., Thessen, A., Matrai, P., Suttles, S., Hill, V., Steele, M., and Light, B.: Synthesis of primary production in the Arctic Ocean: III. Nitrate and phosphate based estimates of net community production, Prog. Oceanogr., 110, 126-150, https://doi.org/10.1016/j.pocean.2012.11.006, 2013.

Cury, P. and Roy, C.: Optimal Environmental Window and Pelagic Fish Recruitment Success in Upwelling Areas, Can. J. Fish. Aquat. Sci., 46, 670-680, https://doi.org/10.1139/f89-086, 1989.

Dee, D. P., Uppala, S. M., Simmons, A. J., Berrisford, P., Poli, P., Kobayashi, S., Andrae, U., Balmaseda, M. A., Balsamo, G., Bauer, P., Bechtold, P., Beljaars, A. C. M., van de Berg, L., Bidlot, J., Bormann, N., Delsol, C., Dragani, R., Fuentes, M., Geer, A. J., Haimberger, L., Healy, S. B., Hersbach, H., Hólm, E. V., Isaksen, L., Kållberg, P., Köhler, M., Matricardi, M., McNally, A. P., Monge-Sanz, B. M., Morcrette, J.-J., Park, B.-K., Peubey, C., de Rosnay, P., Tavolato, C., Thépaut, J.-N., and Vitart, F.: The ERA-Interim reanalysis: configuration and performance of the data assimilation system, Q. J. Roy. Meteor. Soc., 137, 553-597, https://doi.org/10.1002/qj.828, 2011.

Falk-Petersen, S., Pavlov, V., Berge, J., Cottier, F., Kovacs, K. M., and Lydersen, C.: At the rainbow's end: high productivity fueled by winter upwelling along an Arctic shelf, Polar Biol., 38, 5-11 https://doi.org/10.1007/s00300-014-1482-1, 2014.

Frey, K. E. and McClelland, J. W.: Impacts of permafrost degradation on arctic river biogeochemistry, Hydrol. Process., 23, 169182, https://doi.org/10.1002/hyp.7196, 2009.

Gruber, N. and Sarmiento, J. L.: Global patterns of marine nitrogen fixation and denitrification, Global Biogeochem. Cy., 11, 235266, https://doi.org/10.1029/97GB00077, 1997.

Haug, T., Bogstad, B., Chierici, M., Gjøsæter, H., Hallfredsson, E. H., Høines, A. S., Hoel, A. H., Ingvaldsen, R. B., Jørgensen, L. L., Knutsen, T., Loeng, H., Naustvoll, L.-J., Røttingen, I., and Sunnanå, K.: Future harvest of living resources in the Arctic Ocean north of the Nordic and Barents Seas: A review of possibilities and constraints, Fish. Res., 188, 38-57, https://doi.org/10.1016/j.fishres.2016.12.002, 2017.

Hunt, G. L., Drinkwater, K. F., Arrigo, K., Berge, J., Daly, K., Danielson, S., Daase, M., Hop, H., Isla, E., Karnovsky, N., Laidre, K., Mueter, F. J., Murphy, E. J., Renaud, P. E., Smith, W. O., Trathan, P., Turner, J., and Wolf-Gladrow, D.: Advection in polar and sub-polar environments: Impacts on high latitude marine ecosystems, Prog. Oceanogr., 149, 40-81, https://doi.org/10.1016/j.pocean.2016.10.004, 2016.
Ivanov, V., Alexeev, V., Koldunov, N. V., Repina, I., Sandø, A. B., Smedsrud, L. H., and Smirnov, A.: Arctic Ocean heat impact on regional ice decay - a suggested positive feedback, J. Phys. Oceanogr., 46, 1437-1456, https://doi.org/10.1175/jpo-d15-0144.1, 2016.

Jakobsson, M., Mayer, L., Coakley, B., Dowdeswell, J. A., Forbes, S., Fridman, B., Hodnesdal, H., Noormets, R., Pedersen, R., Rebesco, M., Schenke, H. W., Zarayskaya, Y., Accettella, D., Armstrong, A., Anderson, R. M., Bienhoff, P., Camerlenghi, A., Church, I., Edwards, M., Gardner, J. V., Hall, J. K., Hell, B., Hestvik, O., Kristoffersen, Y., Marcussen, C., Mohammad, R., Mosher, D., Nghiem, S. V., Pedrosa, M. T., Travaglini, P. G., and Weatherall, P.: The International Bathymetric Chart of the Arctic Ocean (IBCAO) Version 3.0, Geophys. Res. Lett., 39, L12609, https://doi.org/10.1029/2012GL052219, 2012.

Kämpf, J. and Chapman, P.: Upwelling Systems of the World, Springer, Switzerland, 2016.

Koenig, Z., Provost, C., Villacieros-Robineau, N., Sennéchael, N., Meyer, A., Lellouche, J.-M., and Garric, G.: Atlantic waters inflow north of Svalbard: Insights from IAOOS observations and Mercator Ocean global operational system during N-ICE2015, J. Geophys. Res.-Oceans, 122, 1254-1273, https://doi.org/10.1002/2016JC012424, 2017.

Li, W. K. W., McLaughlin, F. A., Lovejoy, C., and Carmack, E. C.: Smallest Algae Thrive As the Arctic Ocean Freshens, Science, 326, 539-539, https://doi.org/10.1126/science.1179798, 2009.

Li, W. K. W., Carmack, E. C., McLaughlin, F. A., Nelson, R. J., and Williams, W. J.: Space-for-time substitution in predicting the state of picoplankton and nanoplankton in a changing Arctic Ocean, J. Geophys. Res.-Oceans, 118, 5750-5759, https://doi.org/10.1002/jgrc.20417, 2013.

Lin, P., Pickart, R. S., Stafford, K. M., Moore, G. W. K., Torres, D. J., Bahr, F., and Hu, J.: Seasonal variation of the Beaufort shelfbreak jet and its relationship to Arctic cetacean occurrence, J. Geophys. Res.-Oceans, 121, 8434-8454, https://doi.org/10.1002/2016JC011890, 2016.

Lind, S. and Ingvaldsen, R. B.: Variability and impacts of Atlantic Water entering the Barents Sea from the north, Deep-Sea Res. Pt. I, 62, 70-88, https://doi.org/10.1016/j.dsr.2011.12.007, 2012.

Martin, T., Steele, M., and Zhang, J.: Seasonality and long-term trend of Arctic Ocean surface stress in a model, J. Geophys. Res.Oceans, 119, 1723-1738, https://doi.org/10.1002/2013jc009425, 2014.

Maslanik, J. A., Fowler, C., Stroeve, J., Drobot, S., Zwally, J., Yi, D., and Emery, W.: A younger, thinner Arctic ice cover: Increased potential for rapid, extensive sea-ice loss, Geophys. Res. Lett., 34, L24501, https://doi.org/10.1029/2007GL032043, 2007.

Morison, J., Kwok, R., Peralta-Ferriz, C., Alkire, M., Rigor, I., Andersen, R., and Steele, M.: Changing Arctic Ocean freshwater pathways, Nature, 481, 66-70, https://doi.org/10.1038/nature10705, 2012.

Onarheim, I. H., Smedsrud, L. H., Ingvaldsen, R. B., and Nilsen, F.: Loss of sea ice during winter north of Svalbard, Tellus A, 66, 23933, https://doi.org/10.3402/tellusa.v66.23933, 2014.

Osborn, T. R.: Estimates of the Local Rate of Vertical Diffusion from Dissipation Measurements, J. Phys. Oceanogr., 10, 83-89, https://doi.org/10.1175/15200485(1980)010<0083:EOTLRO>2.0.CO;2, 1980. 
Polyakov, I. V., Pnyushkov, A. V., and Timokhov, L. A.: Warming of the Intermediate Atlantic Water of the Arctic Ocean in the 2000s, J. Climate, 25, 8362-8370, https://doi.org/10.1175/jcli-d12-00266.1, 2012.

Polyakov, I. V., Pnyushkov, A. V., Alkire, M. B., Ashik, I. M., Baumann, T. M., Carmack, E. C., Goszczko, I., Guthrie, J., Ivanov, V. V., Kanzow, T., Krishfield, R., Kwok, R., Sundfjord, A., Morison, J., Rember, R., and Yulin, A.: Greater role for Atlantic inflows on sea-ice loss in the Eurasian Basin of the Arctic Ocean, Science, 356, 285-291, https://doi.org/10.1126/science.aai8204, 2017.

Price, J. F. and Sundermeyer, M. A.: Stratified Ekman layers, J. Geophys. Res.-Oceans, 104, 20467-20494, https://doi.org/10.1029/1999JC900164, 1999.

Price, J. F., Weller, R. A., and Schudlich, R. R.: Wind-driven ocean currents and Ekman transport, Science, 238, 1534-1538, 1987.

Proshutinsky, A., Dukhovskoy, D., Timmermans, M.-L., Krishfield, R., and Bamber, J. L.: Arctic circulation regimes, Philos. T. R. Soc. A., 373, 20140160, https://doi.org/10.1098/rsta.2014.0160, 2015.

Randelhoff, A. and Sundfjord, A.: Carbon Bridge CTD hydrography 2014, https://doi.org/10.21334/npolar.2017.f40317d5, 2017.

Randelhoff, A., Sundfjord, A., and Reigstad, M.: Seasonal variability and fluxes of nitrate in the surface waters over the Arctic shelf slope, Geophys. Res. Lett., 42, 3442-3449, https://doi.org/10.1002/2015g1063655, 2015.

Randelhoff, A., Reigstad, M., Chierici, M., Sundfjord, A., Ivanov, V., Cape, M., Vernet, M., Tremblay, J.-E., Bratbak, G., and Kristiansen, S.: Seasonality of the physical and biogeochemical hydrography of the Fram Strait branch, Frontiers in Marine Science, submitted, 2018.

Renner, A. H., Hendricks, S., Gerland, S., Beckers, J., Haas, C., and Krumpen, T.: Large-scale ice thickness distribution of first-year sea ice in spring and summer north of Svalbard, Ann. Glaciol., 54, 13-18, https://doi.org/10.3189/2013AoG62A146, 2013.

Renner, A. H., Sundfjord, A., Janout, M. A., Ingvaldsen, R. B., Beszczynska-Möller, A., Pickart, R. S., and Pérez-Hernández, M. D.: Variability and redistribution of heat in the Atlantic Water boundary current north of Svalbard, J. Geophys. Res., in review, 2018.

Rudels, B.: Arctic Ocean stability: The effects of local cooling, oceanic heat transport, freshwater input, and sea ice melt with special emphasis on the Nansen Basin, J. Geophys. Res.-Oceans, 121, 4450-4473, https://doi.org/10.1002/2015jc011045, 2016.

Schulze, L. M. and Pickart, R. S.: Seasonal variation of upwelling in the Alaskan Beaufort Sea: Impact of sea ice cover, J. Geophys. Res.-Oceans, 117, C06022, https://doi.org/10.1029/2012JC007985, 2012.
Serreze, M. C. and Barrett, A. P.: Characteristics of the Beaufort Sea High, J. Climate, 24, 159-182, https://doi.org/10.1175/2010JCLI3636.1, 2011.

Spall, M. A., Pickart, R. S., Brugler, E. T., Moore, G., Thomas, L., and Arrigo, K. R.: Role of shelfbreak upwelling in the formation of a massive under-ice bloom in the Chukchi Sea, Deep-Sea Res. Pt. II, 105, 17-29, https://doi.org/10.1016/j.dsr2.2014.03.017, 2014.

Stroeve, J. C., Serreze, M. C., Holland, M. M., Kay, J. E., Malanik, J., and Barrett, A. P.: The Arctic's rapidly shrinking sea ice cover: a research synthesis, Climatic Change, 110, 1005-1027, https://doi.org/10.1007/s10584-011-0101-1, 2012.

Tetzlaff, A., Lüpkes, C., Birnbaum, G., Hartmann, J., Nygård, T., and Vihma, T.: Brief Communication: Trends in sea ice extent north of Svalbard and its impact on cold air outbreaks as observed in spring 2013, The Cryosphere, 8, 1757-1762, https://doi.org/10.5194/tc-8-1757-2014, 2014.

Tremblay, J.-E., Anderson, L. G., Matrai, P., Coupel, P., Bélanger, S., Michel, C., and Reigstad, M.: Global and regional drivers of nutrient supply, primary production and $\mathrm{CO}_{2}$ drawdown in the changing Arctic Ocean, Prog. Oceanogr., 139, 171-196, https://doi.org/10.1016/j.pocean.2015.08.009, 2015.

Våge, K., Pickart, R. S., Pavlov, V., Lin, P., Torres, D. J., Ingvaldsen, R., Sundfjord, A., and Proshutinsky, A.: The Atlantic Water boundary current in the Nansen Basin: Transport and mechanisms of lateral exchange, J. Geophys. Res.-Oceans, 121, 69466960, https://doi.org/10.1002/2016jc011715, 2016.

Wang, W. and Huang, R. X.: Wind Energy Input to the Ekman Layer, J. Phys. Oceanogr., 34, 1267-1275, https://doi.org/10.1175/15200485(2004)034<1267:WEITTE>2.0.CO;2, 2004.

Wassmann, P., Kosobokova, K., Slagstad, D., Drinkwater, K., Hopcroft, R., Moore, S., Ellingsen, I., Nelson, R., Carmack, E., Popova, E., and Berge, J.: The contiguous domains of Arctic Ocean advection: Trails of life and death, Prog. Oceanogr., 139, 42-65, https://doi.org/10.1016/j.pocean.2015.06.011, 2015.

Williams, W. J. and Carmack, E. C.: The "interior" shelves of the Arctic Ocean: Physical oceanographic setting, climatology and effects of sea-ice retreat on cross-shelf exchange, Prog. Oceanogr., 139, 24-41, https://doi.org/10.1016/j.pocean.2015.07.008, 2015.

Williams, W. J., Carmack, E. C., Shimada, K., Melling, H., Aagaard, K., Macdonald, R. W., and Ingram, R. G.: Joint effects of wind and ice motion in forcing upwelling in Mackenzie Trough, Beaufort Sea, Cont. Shelf Res., 26, 2352-2366, https://doi.org/10.1016/j.csr.2006.06.012, 2006. 